\title{
Influence of pH-control in phosphoric acid treatment of zinc oxide
}

\author{
(Influência do controle do pH no tratamento de \\ óxido de zinco com ácido fosfórico)
}

\author{
H. Onoda ${ }^{1}$, M. Chemel ${ }^{2}$ \\ ${ }^{1}$ Department of Informatics and Environmental Sciences, Kyoto Prefectural University, 1-5, \\ Shimogamo Nakaragi-cyo, Sakyo-ku, Kyoto 606-8522, Japan \\ ${ }^{2}$ Ecol de Biologie Industrielle, 32 Boulevard du Port, 95094 CERGY Cedex, France \\ onoda@kpu.ac.jp
}

\begin{abstract}
Zinc oxide is often used as a white pigment for cosmetics; however, it shows photocatalytic activity that causes decomposition of sebum on the skin when exposed to the ultraviolet radiation in sunlight. In this work, zinc oxide was reacted with phosphoric acid at various $\mathrm{pH}$ values to synthesize a novel white pigment for cosmetics. The chemical composition, powder properties, photocatalytic activities, colors, and smoothness of these pigments were studied. The obtained materials exhibited X-ray diffraction peaks relating to zinc oxide and phosphate after phosphoric acid treatment. The ratio of zinc phosphate to zinc oxide was estimated from inductively coupled plasma - atomic emission spectroscopy results. Samples treated at pH 4-7 yielded small particles with sub-micrometer sizes. The photocatalytic activity of zinc oxide became lower after phosphoric acid treatment. Samples treated at $\mathrm{pH}$ 4-7 showed the same reflectance as zinc oxide in both the ultraviolet and visible ranges. Adjustment of the $\mathrm{pH}$ was found to be important in the phosphoric acid treatment of zinc oxide.
\end{abstract}

Keywords: zinc oxide, phosphoric acid treatment, photocatalytic activity, particle size.

\section{Resumo}

O óxido de zinco é comumente usado como um pigmento branco para cosméticos; entretanto, apresenta atividade fotocatalítica que provoca a decomposição do sebo na pele quando exposto à radiação ultravioleta na luz solar. Neste trabalho, o óxido de zinco foi reagido com ácido fosfórico em vários valores de pH para sintetizar um novo pigmento branco para cosméticos. Foram estudadas a composição química, as propriedades do pó, as atividades fotocatalíticas, as cores e a lisura desses pigmentos. Os materiais obtidos exibiram picos de difração de raios X relacionados com óxido e fosfato de zinco após tratamento com ácido fosfórico. A proporção de fosfato de zinco para óxido de zinco foi estimada a partir de resultados de espectrometria de emissão atômica por plasma acoplado indutivamente. As amostras tratadas em $\mathrm{pH} 4$ a 7 produziram pequenas partículas com tamanhos submicrométricos. A atividade fotocatalítica do óxido de zinco tornou-se menor após o tratamento com ácido fosfórico. As amostras tratadas em $\mathrm{pH} 4$ a 7 apresentaram a mesma reflectância que o óxido de zinco nas faixas do ultravioleta e visível. Verificou-se que o ajuste do pH foi importante no tratamento do óxido de zinco com ácido fosfórico.

Palavras-chave: óxido de zinco, tratamento com ácido fosfórico, atividade fotocatalítica, tamanho de partícula.

\section{INTRODUCTION}

Zinc oxide is used in cosmetic applications as a white pigment [1]. This oxide is well known for its photocatalytic activity [2], causing a certain degree of decomposition of sebum on the skin in the presence of the ultraviolet radiation in sunlight. Several technical processes have been investigated and used to repress this effect: for example, the use of composite particles with silicon oxide [3]. However, these composite materials are too hard for use on a human face, where softer materials are required for use as white pigments. In addition, one study has reported that microfine zinc oxide is adsorbed through the skin [4]. A novel white pigment that is not adsorbed must be used.

Phosphates have been used in ceramic materials, catalysts, adsorbent, fluorescent materials, dielectric substances, biomaterials, metal surface treatments, fertilizers, detergents, food additives, fuel cells, pigments, and other applications [5-8]. Phosphate materials are well known to be bio-compatible. Therefore, phosphates are expected to be useful as novel white pigments in cosmetics. When used as a cosmetic pigment, both the particle shape and size distribution of the phosphate particles are important. Homogeneous spherical particles are expected to spread well on the skin [9], however overly small particles are unsuitable because the pigments may enter the pores of the skin. Generally, sub-micrometer pigments are used. The standard size of white pigment particles used in cosmetics is difficult to determine because the pore sizes of the skin are affected by factors such as age, gender, and climate [10]. Furthermore, overly large particles are inappropriate as their coatings may crack on the skin [11]. It is therefore important 
to control the particle sizes in pigments. In earlier studies [12, 13], we prepared zinc phosphate pigments with no catalytic activity. However, these zinc phosphates had particle sizes larger than $1 \mu \mathrm{m}$. Because these particles were too large, a novel process was required to produce smaller particles as a white pigment. Despite showing no photocatalytic activity, the zinc phosphate particles were too large, while on the other hand, zinc oxide is capable of reaching smaller particle sizes but exhibits photocatalytic activity. In this work, we investigate zinc oxide particles with a zinc phosphate coating. The target particles have a core-shell structure, with a core of zinc oxide and a shell of zinc phosphate. Our purpose in this work was to obtain a novel white pigment of submicrometer size that did not show photocatalytic activity. In this work, zinc oxide was shaken with phosphoric acid in solutions of varying $\mathrm{pH}$. The chemical compositions, powder properties, photocatalytic activities, colors, and smoothness of the obtained precipitates and their thermal products were studied, with potential cosmetic applications in mind.

\section{EXPERIMENTAL}

A $0.1 \mathrm{~mol} / \mathrm{L}$ of aqueous solution of phosphoric acid

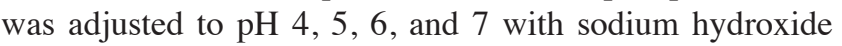
solution. Zinc oxide was added to the phosphoric acid solutions $(50 \mathrm{~mL})$ in a glass tube at a molar ratio of $\mathrm{P}: \mathrm{Zn}=$ $1: 1$, then shaken in water at $80^{\circ} \mathrm{C}$ for $1 \mathrm{~h}$. A phosphoric acid solution without $\mathrm{pH}$ adjustment ( $\mathrm{pH}$ 1.65) was also used as a comparison. The powder samples were decanted, washed with water, and dried. All chemicals were purchased from Wako Chemical Industries (Osaka, Japan), of commercial purity, and used without further purification.

The phase analyses of these materials were performed by using X-ray diffraction (XRD). The XRD patterns were recorded on an X-ray diffractometer (MiniFlex, Rigaku) using monochromatic $\mathrm{CuK} \alpha$ radiation. Samples were also heated to $100{ }^{\circ} \mathrm{C}$ under atmospheric conditions, and the resulting thermal products were also analyzed using their XRD patterns. Infrared (IR) spectra of samples were recorded with a Horiba FT-IR 720 using the KBr disk method. Samples were dissolved in a hydrochloric acid solution, and the ratios of phosphorus to zinc in the precipitates were calculated based on the inductively coupled plasma (ICP) atomic emission spectroscopy results of these solutions using an SPS1500VR from Seiko Instruments. The shapes and sizes of the precipitate particles, as well as their thermal products after heating to $100{ }^{\circ} \mathrm{C}$, were estimated from scanning electron microscopy (SEM) images and particle size distributions. SEM images of the sample powders were observed using a JSM-5510LV (JEOL). The particle size distributions were measured using a centrifugal precipitation particle-size distribution analyzer (SA-CP3L, Shimadzu).

The cosmetic properties investigated were the photocatalytic activity, color and smoothness. The photocatalytic activity of samples was estimated by measuring the degradation or decoloration of methylene blue under $365 \mathrm{~nm}$ radiation $[14,15]$. The samples $(0.01 \mathrm{~g})$ were placed in $4 \mathrm{~mL}$ of methylene blue aqueous solution $\left(1.0 \times 10^{-5} \mathrm{~mol} / \mathrm{L}\right)$, and then this solution was radiated. The decrease in absorption at $660 \mathrm{~nm}$ was estimated over the course of $120 \mathrm{~min}$. The color of the phosphate pigments was estimated using ultraviolet-visible (UV-Vis) reflectance spectroscopy with a spectrometer (UV2100, Shimadzu; reference compound was $\mathrm{BaSO}_{4}$ ). The whiteness was also estimated with a TES135 Plus Color Analyzer (TES Electrical Electronic). Particle smoothness was measured on artificial leather via objective evaluation of surface friction using a KES-SE (Kato Tech). Sample powders (ca. $50 \mathrm{mg}$ ) were spread onto the leather, and a sensor was then run over the powders (scan speed: $1 \mathrm{~mm} / \mathrm{s}$; area scanned: $3 \mathrm{~cm}^{2}$ ). The terms MIU and MMD represent the slipping resistance $(\mu$, average value in a distance of $20 \mathrm{~mm}$ ) and the roughness of the powders (fluctuation of average frictional coefficient), respectively. The values of MIU and MMD are dimensionless because these values are related to the coefficients of friction and scattering, respectively. The dispersions of the MIU and MMD values were 0.03 and 0.002 , respectively, with measurements carried out in triplicate.

\section{RESULTS AND DISCUSSION}

\section{Phase analysis}

Fig. 1 shows XRD patterns of samples prepared at various $\mathrm{pH}$ values and then heated to $100{ }^{\circ} \mathrm{C}$. Phosphoric

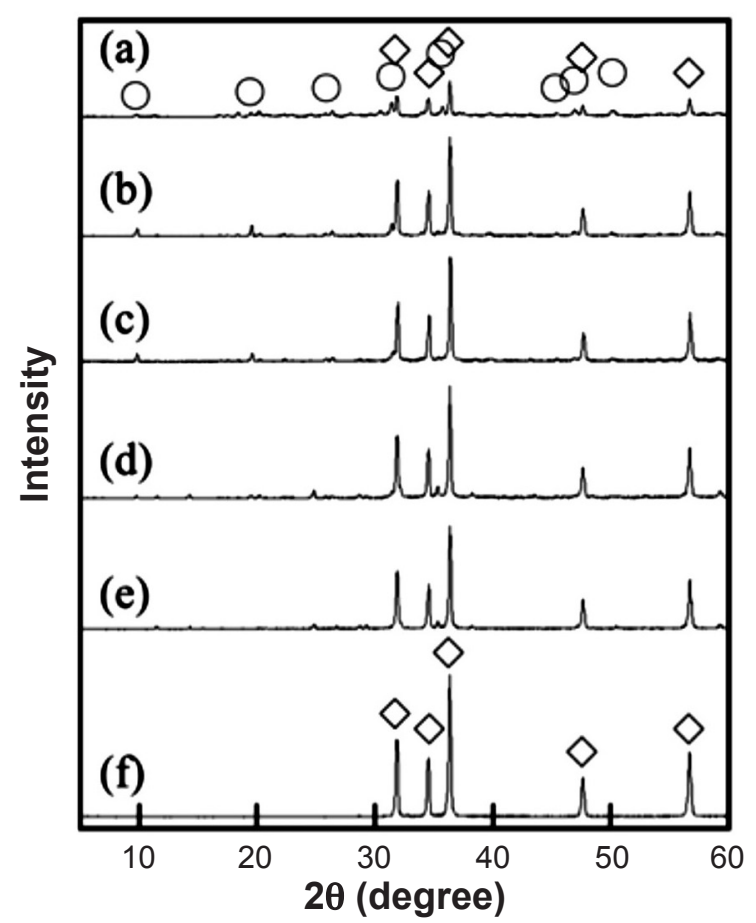

Figure 1: X-ray diffraction patterns of samples prepared at various $\mathrm{pH}$, and then heated at $100{ }^{\circ} \mathrm{C} ; \mathrm{pH}$ at: (a) 1.65 , (b) 4, (c) 5, (d) 6, (e) 7 , and (f) original $\mathrm{ZnO} . \diamond-\mathrm{ZnO} ; \mathrm{O}-\mathrm{Zn}_{3}\left(\mathrm{PO}_{4}\right)_{2} \cdot 4 \mathrm{H}_{2} \mathrm{O}$.

[Figura 1: Difratogramas de raios $X$ de amostras preparadas em vários pH e depois aquecidas a $100{ }^{\circ} \mathrm{C}$; $\mathrm{pH} \mathrm{em:} \mathrm{(a)} \mathrm{1,65,} \mathrm{(b)} \mathrm{4,} \mathrm{(c)}$ 5, (d) 6, (e) 7, e (f) ZnO original.] 


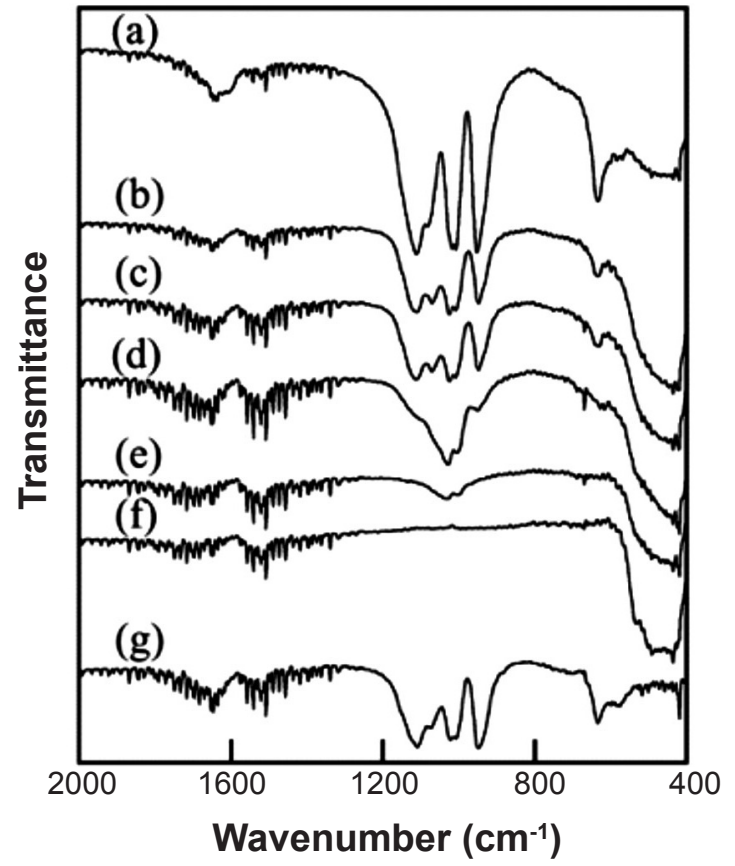

Figure 2: IR spectra of samples prepared at various $\mathrm{pH}$ values, and then heated to $100{ }^{\circ} \mathrm{C} ; \mathrm{pH}$ at: (a) 1.65 , (b) 4, (c) 5, (d) 6, (e) 7, (f) pristine $\mathrm{ZnO}$, and $(\mathrm{g})$ commercial $\mathrm{Zn}_{3}\left(\mathrm{PO}_{4}\right)_{2} \cdot 4 \mathrm{H}_{2} \mathrm{O}$.

[Figura 2: Espectros de infravermelho de amostras preparadas em vários valores de $\mathrm{pH}$ e depois aquecidas a $100^{\circ} \mathrm{C} ; \mathrm{pH} \mathrm{em:} \mathrm{(a)} \mathrm{1,65,}$ (b) 4, (c) 5, (d) 6, (e) 7, (f) $\mathrm{ZnO}$ original, e (g) $\mathrm{Zn}_{3}\left(\mathrm{PO}_{4}\right)_{2} \cdot 4 \mathrm{H}_{2} \mathrm{O}$ comercial.]

Table I - $\mathrm{P} / \mathrm{Zn}$ ratio in samples treated at various $\mathrm{pH}$ values and dried at 50 and $100{ }^{\circ} \mathrm{C}$.

[Tabela I - Relação P/Zn em amostras tratadas em vários valores de $\mathrm{pH}$ e secas a 50 e $100{ }^{\circ} \mathrm{C}$.]

\begin{tabular}{ccc}
\hline $\mathrm{pH}$ & $50{ }^{\circ} \mathrm{C}$ & $100{ }^{\circ} \mathrm{C}$ \\
\hline $1.65^{*}$ & 0.47 & 0.46 \\
4 & 0.16 & 0.17 \\
5 & 0.14 & 0.13 \\
6 & 0.19 & 0.17 \\
7 & 0.13 & 0.10 \\
\hline *-without pH adjustment.
\end{tabular}

acid treatment resulted in the appearance of zinc phosphate peaks. Samples treated at $\mathrm{pH} 1.65$ (i.e., without $\mathrm{pH}$ adjustment), 4, and 5 had stronger zinc phosphate peaks than those treated at $\mathrm{pH} 6$ and 7. On the other hand, peaks related to zinc oxide became smaller after treatment with phosphoric acid, with the sample treated at $\mathrm{pH} 1.65$ showing particularly weak zinc oxide peaks. This confirmed that zinc oxide was converted to zinc phosphate by treatment with phosphoric acid.

Fig. 2 shows the IR spectra of samples prepared at various $\mathrm{pH}$ values and then heated to $100{ }^{\circ} \mathrm{C}$. Samples prepared at $\mathrm{pH} 1.65,4$, and 5 exhibited some absorption peaks related to zinc phosphate at 1110 to $940 \mathrm{~cm}^{-1}$. Broad absorption was observed in the IR spectra of samples treated at pH 6 and
7. These absorption peaks indicated that samples treated at lower $\mathrm{pH}$ contained larger amounts of zinc phosphate.

Table I shows P:Zn ratios in samples prepared at various $\mathrm{pH}$ values, as calculated from ICP measurements. Samples prepared at $\mathrm{pH} 1.65$ were observed to have a higher $\mathrm{P}: \mathrm{Zn}$ ratio than others. Samples prepared at $\mathrm{pH} 4$ to $7 \mathrm{had}$ similar P:Zn ratios. These results did not correspond with the aforementioned IR results. It is difficult to clarify why samples treated at $\mathrm{pH} 4$ to 7 had different IR spectra. The drying temperature had little influence on the P:Zn ratio. When zinc oxide and phosphate were mixed in a molar ratio of $\mathrm{ZnO}: \mathrm{Zn}_{3}\left(\mathrm{PO}_{4}\right)_{2}=2: 1$, the $\mathrm{P}: \mathrm{Zn}$ ratio was $2: 5$, while a molar ratio of $\mathrm{ZnO}: \mathrm{Zn}_{3}\left(\mathrm{PO}_{4}\right)_{2}=7: 1$ resulted in $\mathrm{P}: \mathrm{Zn}=1: 5$. Samples prepared at $\mathrm{pH} 1.65$ had larger amounts of zinc phosphate than other samples.

\section{Powder properties}

Spherical particles are the preferred shape for particles used in cosmetic applications. Fig. 3 shows SEM images of samples prepared at various $\mathrm{pH}$ values and then heated to $100{ }^{\circ} \mathrm{C}$. Sample prepared without $\mathrm{pH}$ adjustment had the largest aggregates, which were approximately $50 \mu \mathrm{m}$ in diameter (Fig. 3a). On the other hand, samples prepared with $\mathrm{pH}$ adjustment had smaller aggregates that were about 10 to $20 \mu \mathrm{m}$ in diameter (Figs. $3 \mathrm{~b}$ to $3 \mathrm{e}$ ). Plate-like particles were
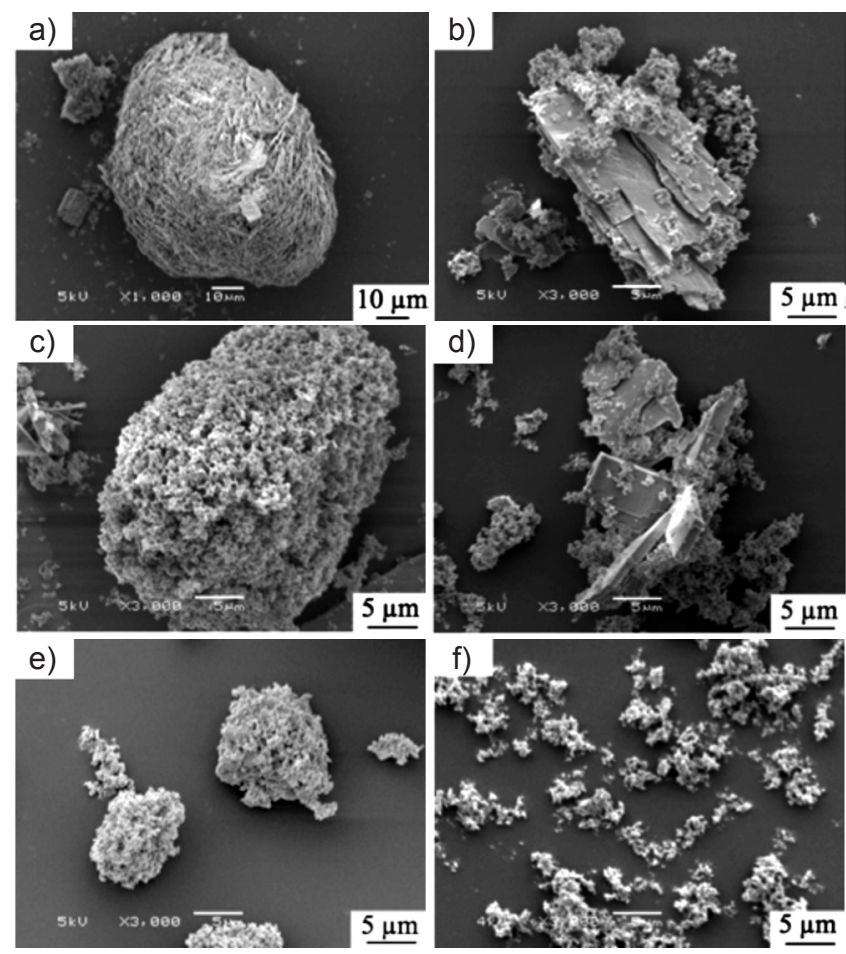

Figure 3: SEM micrographs of samples prepared at various $\mathrm{pH}$ values, and then heated to $100{ }^{\circ} \mathrm{C} ; \mathrm{pH}$ at: (a) 1.65 , (b) 4, (c) 5 , (d) 6, (e) 7, and (f) pristine $\mathrm{ZnO}$.

[Figura 3: Micrografias obtidas por microscopia eletrônica de varredura de amostras preparadas em vários valores de $\mathrm{pH}$ e depois aquecidas a $100{ }^{\circ} \mathrm{C} ; \mathrm{pH} \mathrm{em:} \mathrm{(a)} \mathrm{1,65,} \mathrm{(b)} \mathrm{4,} \mathrm{(c)} \mathrm{5,} \mathrm{(d)} \mathrm{6,} \mathrm{(e)}$ 7, e (f) ZnO original.] 


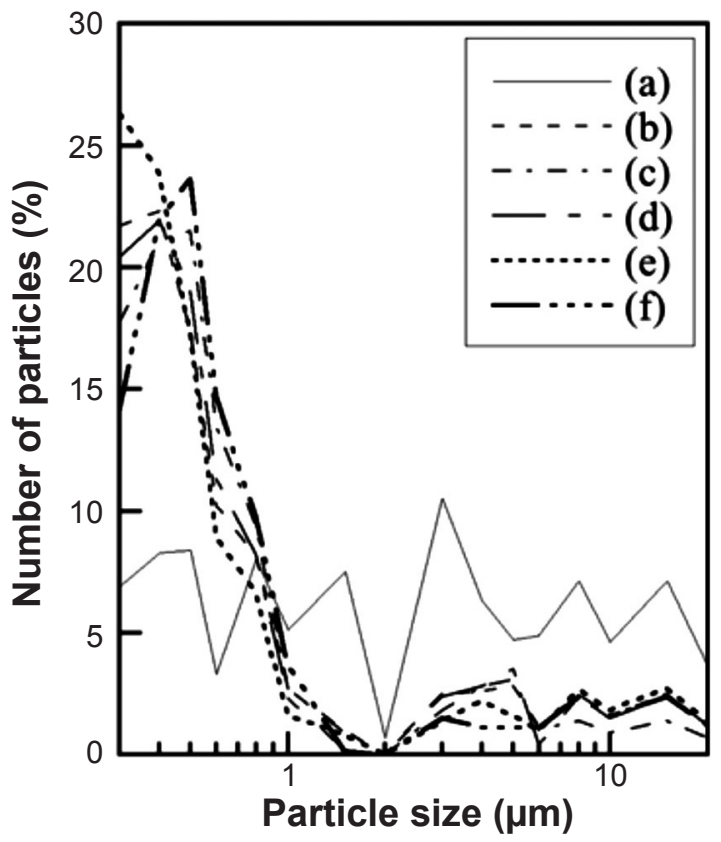

Figure 4: Particle size distributions of samples prepared at various $\mathrm{pH}$ values, and then heated to $100{ }^{\circ} \mathrm{C} ; \mathrm{pH}$ at: (a) 1.65 , (b) 4 , (c) 5 , (d) 6, (e) 7, and (f) pristine $\mathrm{ZnO}$.

[Figura 4: Distribuições granulométricas de amostras preparadas em vários valores de $\mathrm{pH}$ e depois aquecidas a $100{ }^{\circ} \mathrm{C}$; $\mathrm{PH}$ em: (a) 1,65, (b) 4, (c) 5, (d) 6, (e) 7, e (f) $\mathrm{ZnO}$ original.]

observed in samples treated at $\mathrm{pH} 4$ and 6 (Figs. $3 \mathrm{~b}$ and $3 \mathrm{~d}$ ). Samples treated with phosphoric acid had larger particles than pristine zinc oxide. These samples had a possibility to form the aggregate in a drying process, because zinc phosphate and oxide are easy to form [12,13]. For cosmetic applications, inorganic pigments in solution are in common use without drying. Therefore, in this work, the particle size distribution in solution was also estimated.

Fig. 4 shows the particle size distributions of samples prepared at various $\mathrm{pH}$ values and then heated to $100{ }^{\circ} \mathrm{C}$. The ultrasonic treatment before the measurement of the particle size distributions resulted in smaller particle sizes for all samples than those observed via SEM. Samples prepared at $\mathrm{pH} 1.65$ had different particle sizes from the others. From the ICP results, this sample had a larger amount of zinc phosphate than the other samples (Table I), which affected the particle size distribution because zinc phosphate consisted of particles larger than $1 \mu \mathrm{m}[12$, 13]. Other samples had particle sizes smaller than $1 \mu \mathrm{m}$. In general, pigments with sub-micrometer particles are used in cosmetics. Therefore, the samples prepared at $\mathrm{pH} 4$ to $7 \mathrm{had}$ suitable (i.e., sub-micrometer) particle sizes.

\section{Cosmetic properties}

Fig. 5 shows the photocatalytic activity of samples prepared at various $\mathrm{pH}$ values, and then heated to $100{ }^{\circ} \mathrm{C}$. Methylene blue was degraded or decolored by zinc oxide under UV radiation (Fig. $5 \mathrm{~g}$ ), but this photocatalytic activity was inhibited by the phosphoric acid treatment (Figs. 5b

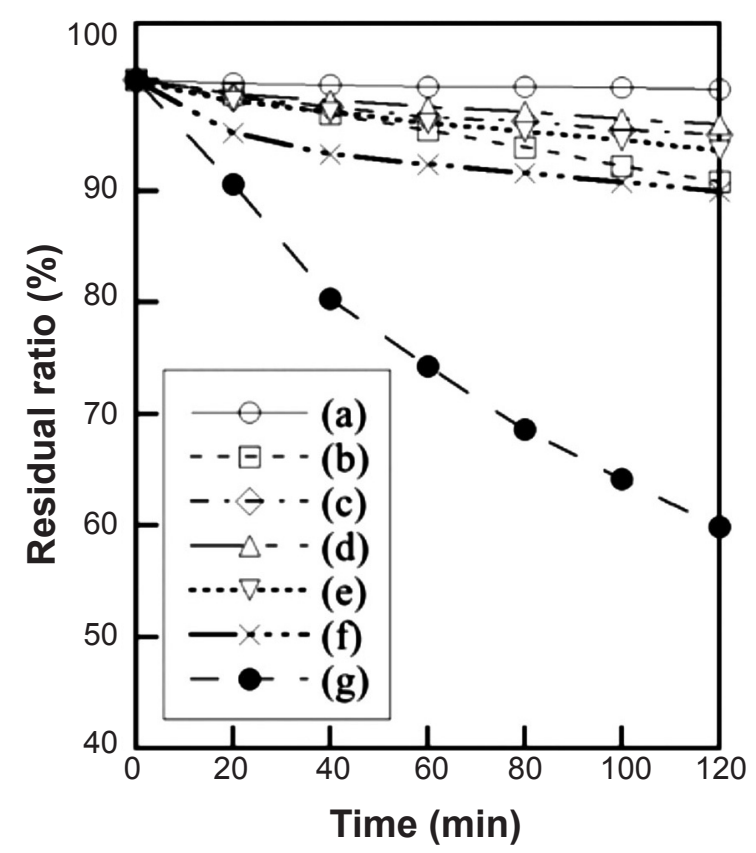

Figure 5: Photocatalytic activities of samples prepared at various $\mathrm{pH}$ values, and then heated to $100{ }^{\circ} \mathrm{C}$; (a) blank, and $\mathrm{pH}$ at: (b) 1.65, (c) 4, (d) 5, (e) 6, (f) 7, and (g) pristine $\mathrm{ZnO}$.

[Figura 5: Atividades fotocatalíticas de amostras preparadas em vários valores de $\mathrm{pH}$ e depois aquecidas a $100^{\circ} \mathrm{C}$; (a) branco; e $\mathrm{pH}$ em: (b) 1,65, (c) 4, (d) 5, (e) 6, (f) 7, e (g) ZnO original.]

to $5 \mathrm{f})$. Samples prepared at $\mathrm{pH} 4$ and 5 indicated weaker photocatalytic activity than those prepared at pH 6 and 7 . The photocatalytic activity of zinc oxide was suppressed by the formation of zinc phosphate, which has no photocatalytic activity $[12,13]$. From the XRD results, samples prepared at pH 1.65 easily reacted with phosphoric acid; however, the large amount of zinc phosphate resulted in the cracking of the zinc phosphate shell, causing the photocatalytic activity of samples prepared at $\mathrm{pH} 1.65$ to be stronger than those prepared at $\mathrm{pH} 4$ and 5 .

Fig. 6 shows the UV-Vis reflectance spectra of samples prepared at various $\mathrm{pH}$ values, and then heated to $100{ }^{\circ} \mathrm{C}$. Samples treated at $\mathrm{pH} 1.65$ had lower reflectance in the visible region than pristine zinc oxide, because of the formation of large particles, which made it easy for visible light to scatter on the particle surface. On the other hand, samples treated with $\mathrm{pH}$ adjustment showed no difference compared to zinc oxide. In the ultraviolet region, samples prepared at $\mathrm{pH}$ 1.65 possessed higher reflectance than those prepared under other conditions. This was due to the high reflectance of zinc phosphate in the ultraviolet region [12], and the high amount of zinc phosphate in this sample as measured by the ICP results (Table I). The colors of the powders were also estimated using a $\mathrm{L}^{*} \mathrm{a} \mathrm{b}^{*}$ color space. Table II shows the whiteness of samples prepared using various conditions, from the $\mathrm{L}^{*}$ values in the $\mathrm{L}^{*} \mathrm{a}^{*} \mathrm{~b}^{*}$ color space. The values of all the samples were high enough to qualify as white pigments $\left(L^{*}>94\right)$. These results corresponded with the above UV-Vis reflectance spectra. On the other hand, the particle size had less influence on the whiteness of particles. 


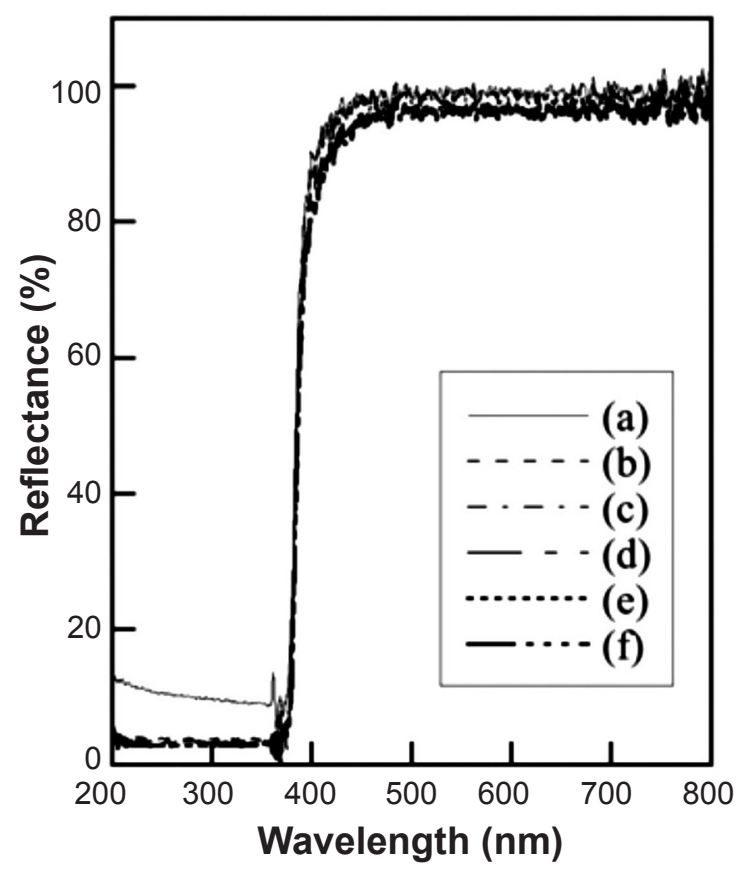

Figure 6: UV-Vis reflectance spectra of samples prepared at various $\mathrm{pH}$ values, and then heated to $100{ }^{\circ} \mathrm{C}$; $\mathrm{pH}$ at: (a) 1.65, (b) 4, (c) 5, (d) 6, (e) 7, and (f) pristine $\mathrm{ZnO}$.

[Figura 6: Espectros de reflectância UV-Vis de amostras preparadas em vários valores de $\mathrm{pH}$ e depois aquecidas a $100{ }^{\circ} \mathrm{C} ; \mathrm{pH} \mathrm{em:} \mathrm{(a)} \mathrm{1,65,} \mathrm{(b)} \mathrm{4,} \mathrm{(c)} \mathrm{5,} \mathrm{(d)} \mathrm{6,} \mathrm{(e)} \mathrm{7,} \mathrm{e} \mathrm{(f)} \mathrm{ZnO}$ original.]

Table II - Whiteness of samples treated at various $\mathrm{pH}$ values and dried at 50 and $100{ }^{\circ} \mathrm{C}$.

[Tabela II - Alvura das amostras tratadas em vários valores de pH e secas a 50 e $100{ }^{\circ} \mathrm{C}$.]

\begin{tabular}{ccc}
\hline $\mathrm{pH}$ & $50{ }^{\circ} \mathrm{C}$ & $100{ }^{\circ} \mathrm{C}$ \\
\hline 1.65 & 97.7 & 98.4 \\
4 & 96.3 & 95.6 \\
5 & 99.1 & 96.8 \\
6 & 94.9 & 96.0 \\
7 & 99.6 & 98.1 \\
\hline
\end{tabular}

Table III - Smoothness parameters of samples treated at various $\mathrm{pH}$ values, and then heated to $100{ }^{\circ} \mathrm{C}$.

[Tabela III - Parâmetros de lisura das amostras tratadas em vários valores de $\mathrm{pH}$ e depois aquecidas a $100{ }^{\circ} \mathrm{C}$.]

\begin{tabular}{ccc}
\hline $\mathrm{pH}$ & $\mathrm{MIU}$ & $\mathrm{MMD}$ \\
\hline 1.65 & 0.28 & 0.014 \\
4 & 0.28 & 0.012 \\
5 & 0.37 & 0.013 \\
6 & 0.38 & 0.013 \\
7 & 0.52 & 0.012 \\
$\mathrm{ZnO}$ & 0.50 & 0.016 \\
\hline
\end{tabular}

As described above, pigments with high smoothness spread well on the skin, meaning powder smoothness is important for cosmetics [16]. Table III shows the smoothness of samples prepared under various conditions. Generally, suitable MIU and MMD values for cosmetic applications are less than 0.6 and less than 0.04, respectively. Samples prepared at $\mathrm{pH} 7$ yielded a similar MIU value to zinc oxide, which agreed with the XRD and ICP results (Fig. 1 and Table I). Samples with higher P:Zn ratios (Table I) gave lower MIU values, while MMD values were less affected by the $\mathrm{pH}$ of the phosphoric acid treatment. Because zinc phosphate had small MIU value [13], the MIU value of samples became smaller by formation of zinc phosphate on the surface of zinc oxide in phosphoric acid treatment.

\section{CONCLUSIONS}

Zinc oxide was shaken in phosphoric acid at various $\mathrm{pH}$ values, with solution $\mathrm{pH}$ being adjusted with sodium hydroxide. The obtained materials showed XRD peaks corresponding to zinc oxide and zinc phosphate after phosphoric acid treatment. The ratio of zinc oxide to phosphate was estimated from ICP results. The photocatalytic activity of zinc oxide became lower after treatment with phosphoric acid. Adjustment of the $\mathrm{pH}$ was found to be important in the phosphoric acid treatment. Samples treated at pH 4-7 yielded small particles with sub-micrometer sizes. Samples treated at $\mathrm{pH} 5$ gave the lowest photocatalytic activity. Samples treated at $\mathrm{pH}$ 4-7 indicated the same reflectance in the both the ultraviolet and visible spectrum as zinc oxide. Samples prepared without $\mathrm{pH}$ adjustment showed less reflectance in the visible region when examined by UV-Vis spectroscopy, which was in accordance with their appearance as a dark powder. After phosphoric acid treatment, the smoothness of samples improved.

\section{ACKNOWLEDGEMENT}

The authors are grateful to Dr. Takeshi Toyama, Nihon University, Japan, for the smoothness measurements.

\section{REFERENCES}

[1] N.A. Monteiro-Riviere, K. Wiench, R. Landsiedel, S. Schulte, A.O. Inman, J. E. Riviere, Toxicol. Sci. 123, 1 (2011) 264.

[2] A. Kajbafvala, H. Ghorbani, A. Paravar, J.P. Samberg, E. Kajbafvala, S.K. Sadrnezhaad, Superlattice. Mictrost. 51, 4 (2012) 512 .

[3] G.J. Nohynek, E.K. Dufour, Arch. Toxicol. 86 (2012) 1063.

[4] V.R. Leite-Silva, M.L. Lamer, W.Y. Sanchez, D.C. Liu, W.H. Sanchez, I. Morrow, D. Martin, H.D.T. Silva, T.W. Prow, J.E. Grice, M.S. Roberts, Europ. J. Pharm. Biopharm. 84, 2 (2013) 297.

[5] W. Weng, R.A. Otaibi, M. Alhumaimess, M. Conte, J.K. Bartley, N.F. Dummer, G.J. Hutchings, C.J. Kiely, J. Mater. 
Chem. 21, 40 (2011) 16136.

[6] X. Zhou, H. Bai, H. Ma, H. Li, W. Yuan, H. Du, P. Zhang, H. Xin, Mater. Charact. 108 (2015) 22.

[7] H. Onoda, T. Funamoto, J. Fluoresc. 25, 2 (2015) 247.

[8] H. Onoda, Y. Inagaki, A. Kuwabara, N. Kitamura, K. Amezawa, A. Nakahira, I. Tanaka, J. Ceram. Process. Res. 11, 3 (2010) 344.

[9] Y. Lee, N.B. Schade, L. Sun, J.A. Fan, D.R. Bae, M.M. Mariscal, G. Lee, F. Capasso, S. Sacanna, V.N. Manoharan, G. Yi, ACS Nano 7, 12 (2013) 11064.

[10] B.Y. Kim, J.W. Choi, K.C. Park, S.W. Youn, Skin Res. Technol. 19, 1 (2011) e45.
[11] S. Yin, Y. Minamidate, S. Tonouchi, T. Goto, Q. Dong, H. Yamane, T. Sato, RSC Adv. 2 (2012) 5976.

[12] H. Onoda, M. Haruki, T. Toyama, Ceram. Int. 40, 2 (2014) 3433.

[13] H. Onoda, M. Haruki, T. Toyama, Int. J. Cosmetic Sci. 36, 4 (2014) 321.

[14] V. Eskizeybek, F. Sari, H. Gülce, A. Gülce, A. Avci, Appl. Catal. B: Environ. 119-120 (2012) 197.

[15] B. Lin, X. Li, B. Xu, Y. Chen, B. Gao, X. Fan, Micropor. Mesopor. Mat. 155 (2012) 16.

[16] L. Xianjuan, X. Haiquan, C. Jing, S. Juncai, Y. Yuxiang, L. Xiangnong, Glass Phys. Chem. 37, 3 (2011) 330.

(Rec. 25/08/2016, Rev. 29/09/2016, Ac. 30/09/2016) 